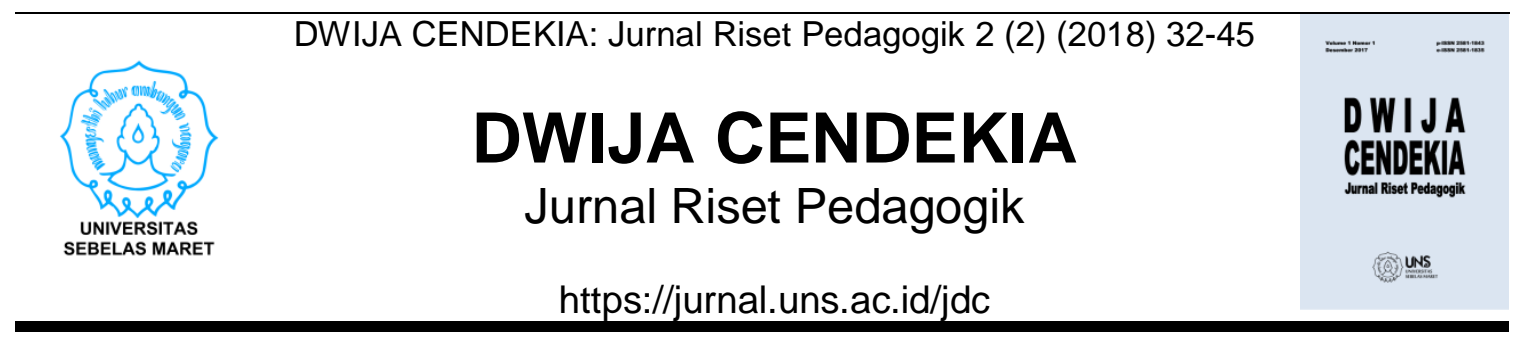

\title{
GROWING DEVELOPING CIVICS LITERACY THROUGH SAINTIFIC LEARNING APPROACH MODEL USING LEARNING MEDIA COMPUTER PRO SHOW GOLD APPLICATION
}

\author{
Fatahillah, Mulat Sudrajat, Ari Rohmawati \\ STKIP Muhammadiyah Pringsewu Lampung
}

\section{Sejarah Artikel}

Diterima 20 Oktober 2018

Disetujui 26 Desember 2018

Diterbitkan 31 Desember 2018

Kata Kunci

Civics Literacy, Scientific

Learning, Computer-based

Learning Media.

\begin{abstract}
Abstrak
Developing Civic Literacy for a citizen of a young country is a pedagogical mission that must be borne by every educator directed by the 2013 Curriculum through the use of Scientific approaches in various learning activities that require learning media that can arouse students' rational and intellectual thinking ability, namely Audio Visual Media namely a media based on multimedia with computer hardware and run based on software programs namely; Pro Gold Show. Researchers intend to carry out an Action Research (Action Research) which aims to examine the Impact of the Use of Scientific Learning-Based Models Using Computer Application Media Pro Gold Show Research will be carried out through three cycles namely planning, acting, observing and Reflection and analyzed by SWOT (Strenghts Weakness Opportunities Threats). This study was conducted to develop a hypothetical model using a qualitative approach, while the results of the study showed that the Action Model had the power: Can provide a more effective and simple transformation of knowledge through a series of stages of Action, Weaknesses: Learning using an old style that is Cross Curricular will hinder innovation and improvisation: Opportunities: Still open Innovation and Improvisation in its development; Threat: Creativity that is not formed due to the lack of ability of the Teacher will result in actions in learning to be in vain".

\section{Cara Mengutip}

Fatahillah, Sudrajat, M., Rohmawati, A. (2018). Growing Developing Civics Literacy Throuhh Saintific Learning Approach Model Using Learning Media Computer Pro Show Gold Application. DWIJA CENDEKIA Jurnal Riset Pedagogik, 2 (2), 32-45
\end{abstract}




\section{PENDAHULUAN}

Membangun literasi sebagai bagian dari watak peserta didik sejak dini. $\mathrm{Hal}$ tersebut telah menjadi sebuah misi pedagogis yang harus dipikul oleh setiap tenaga pendidik. Kemampuan literasi harus diupayakan dengan berbagai pendekatan dan metode karena tuntutan keterampilan memahami mengenai informasi secara analitis, kritis, dan reflektif merupakan sesuatu hal yang harus dimiliki di era global ini.

Kemampuan literasi siswa di Indonesia berada pada peringkat ke- 57 dari 65 negara dengan skor 396 dan tahun 2012 pada peringkat ke-64 dari 65 negara $(O E C D, 2013$, Ditjen Dikdasmen Kemendikbud RI, 2016:1). Data-data statistik yang disuguhkan ini telah memberikan gambaran bahwa tingkat kemampuan Literasi di Indonesia masih sangat rendah. Oleh karena itu, terdapat tiga hal yang harus dipersiapkan pendidikan sebagai bekal bagi warga negaranya, Pertama; Pengetahuan mengenai Kewarganegaraan (Civics Knowledge) yakni; pengetahuanpengetahuan yang seharusnya dan sebaiknya dimiliki oleh Warga negara secara individual Kedua; Kecakapan Kewarganegaraan (Civics Skill) ialah kemampuan Warga Negara dalam; 1) Interaksi (interacting) yakni: dalam berkomunikasi dan bekerjasama dengan orang lain, 2) Monitoring digambarkan sebagai kemampuan untuk terlibat dalam proses politik dan pemerintahan, dan 3) Influencing yaitu kecakapan parsipatoris dalam mempengaruhi politik dan pemerintahan. Ketiga; Watak Kewarganegaraan (Civics Disposition) di deskripsikan sebagai karakter yang penting untuk dimiliki oleh seorang Warga negara (Winataputra dan Budimansyah, 2007:186-192).

Upaya mempersiapkan hal-hal sebagaimana yang telah diuraikan di atas dapat dilakukan melalui; (Wahab dan Sapriya, 2011:47-54): Learning to know (Belajar untuk memahami), Learning to do

(Belajar untuk berbuat sesuatu), Learning to Live Together (Belajar untuk Hidup Bersama), dan Learning To be (Belajar untuk menjadi sesuatu).

Kurikulum 2013 yang diberlakukan saat ini dipayungi hukum melalui penerbitan Permendikbud No. 20, 21, 22, dan 23 Tahun 2016 tentang Standar Kompetensi Lulusan, Standar Isi, Standar Proses dan Standar Penilaian Kurikulum 2013, telah memberikan arahan bahwa Pendekatan yang dapat dipergunakan yaitu; a) Pembelajaran saintifik; b) Pembelajaran berbasis Aktivitas; c) Pembelajaran Kolaboratif; d) Pembelajaran Berbasis Proyek; dan e) Pembelajaran Discovery. (Ditjen Dikdasmen Kemendikbud RI, 2016:20).

Pendekatan Pembelajaran

Saintifik merupakan suatu pendekatan dalam kegiatan belajar mengajar yang mengajarkan siswa untuk aktif mengkonstruksikan konsep, prinsip atau teori melalui langkah-langkah mengamati, menanya, menalar, mengumpulkan informasi/mencoba, menganalisis data dan menarik kesimpulan yang kemudian ia komunikasikan konsep, prinsip atau teori yang ditemukan.

Dalam

mengimplementasikan

Saintifik terutama dalam tahapan kegiatan mengamati memerlukan alat bantu media pembelajaran yang bersifat Audio Visual, karena harus melibatkan Panca Indera dalam kegiatan observasinya.

Media Pembelajaran Audio Visual menurut Slamet (2015:69) dalam penggunaannya dapat meningkatkan partisipasi dan prestasi belajar pada siswa sekolah Dasar, bahkan mampu meningkatkan kinerja Guru dalam Mengajar. Media Audio Visual merupakan suatu media alat bantu pengajaran yang mampu menampilkan teks, gerak, suara, dan gambar (Slamet, 2015:62).

Tepat sekali apabila dalam melaksanakan pembelajaran dengan 
menggunakan Pendekatan saintifik kita menggunakan Media Audio Visual karena dirasakan akan mampu mencapai tujuan dari pembelajaran tercapai secara maksimal.

Media Pembelajaran Audio Visual dapat dijalankan menggunakan piranti Komputer, VCR, dan peralatan Multimedia lainnya, dengan Aplikasi Komputer didalamnya sebagai program atau sistem untuk menjalankannya atau membuatnya.

Salah satu bentuk Media Pembelajaran Audio Visual terdapat suatu media yang berbasis multimedia dengan perangkat keras Komputer dan dijalankan berdasarkan program perangkat lunak yakni; Pro Gold Show.

Pro Gold Show adalah suatu Aplikasi Komputer yang dipergunakan untuk menggabungkan tampilan-tampilan gambar sehingga menjadi satu kesatuan penayangan. Media ini dapat dipergunakan oleh tenaga pengajar untuk menampilkan pesan-pesan materi belajar menjadi satu kesatuan pendekatan pembelajaran saintifik.

Berdasarkan uraian fenomena yang telah disampaikan, kami mencoba untuk mencoba menyusun dan mengembangkan langkah-langkah model pembelajaran berbasis pendekatan Saintifik dengan menggunakan media belajar Aplikasi Komputer Pro Show Gold dalam rangka menumbuhkan Civic Literacy di kalangan Siswa Sekolah Dasar.

Dasar pertimbangan kami mengambil Model ini karena disinyalir; 1) Guru dalam menerangkan materi kepada siswa masih cenderung membosankan (Slamet, 2015: 61); 2) Guru belum memiliki kemampuan untuk menjadi sumber pengetahuan bagi muridnya dikarenakan keterbatasan pengetahuan yang dimilikinya (Fatahillah, 2017: 72-73); 3) Guru belum mampu mengidentifikasi apa yang harus ia lakukan dalam pembelajaran (Fatahillah, 2017: 72-73); dan 4) Guru sangat pasif dalam menggali minat dan bakat siswa, dikarenakan monotonnya kegiatan pembelajaran, sehingga peran ia sebagai motivator, Inspirator, fasilitator, Rekan Sejawat, dan Evaluator belum secara maksimal tercapai, di mana kenyataan temuan empiris menunjukkan Guru baru berperan sebagai fasilitator belaka yakni sebagai penyedia jasa layanan pendidikan bukan pendidik yang mampu memberikan pencerahan (Fatahillah, 2017: 73).

Menimbangkan permasalahan yang dikemukakan di atas dapat kita tarik beberapa pertanyaan sebagai landasan atau pokok kajian dalam penelitian yakni; 1) Bagaimana gambaran tingkat kemampuan civics literacy pada siswa kelas tinggi SD Muhammadiyah Pringsewu Lampung? 2) Bagaimana langkah-langkah instruksi penggunaan model berbasis pembelajaran saintifik dengan menggunakan media belajar aplikasi komputer Pro Gold Show untuk menumbuhkembangkan civic literacy siswa sekolah dasar pada siswa kelas tinggi SD Muhammadiyah Pringsewu Lampung? 3) Bagaimana gambaran dampak penggunaan model berbasis pembelajaran saintifik dengan menggunakan media belajar aplikasi komputer Pro Show Gold untuk menumbuhkembangkan civic literacy siswa Sekolah Dasar pada siswa kelas tinggi SD Muhammadiyah Pringsewu Lampung? 4) Bagaimana kekuatan, kelemahan, tantangan dan hambatan dalam penggunaan model berbasis pembelajaran saintifik dengan menggunakan media belajar aplikasi komputer Pro Gold Show untuk menumbuhkembangkan civic literacy siswa Sekolah Dasar pada siswa kelas tinggi SD Muhammadiyah Pringsewu Lampung?

\section{METODE PENELITIAN}

Penelitian ini akan menggunakan Metode Penelitian Tindakan (Action
Research) yakni suatu penelitian yang berupaya untuk mengidentifikasi suatu 
masalah, melakukan sesuatu untuk memecahkan masalah, dan mengamati bagaimana keberhasilannya dengan cara memberdayakan semua partisipan dalam proses belajar dengan maksud memberikan koreksi pada praktik pendidikan (Emzir 2014:233-235). Adapun Penelitian akan dilaksanakan di Sekolah Dasar Muhammadiyah di Kabupaten Pringsewu Lampung dengan Waktu Penelitian dipergunakan adalah semester Ganjil Tahun Ajaran 2018/2019 yakni pada bulan Agustus sampai bulan Desember 2018. Penentuan disesuaikan dengan kalender Pendidikan yang telah ditentukan.

Adapun Subyek Penelitian Tindakan ini adalah Siswa Kelas Tinggi Sekolah Dasar Muhammadiyah di Kabupaten Pringsewu Lampung sebagai Peserta didik, yakni siswa kelas IV yang sedang mengikuti pembelajaran tematik berdasarkan Kurikulum 2013, sedangkan obyek penelitiannya yaitu; kemampuan Civics Literasi siswa kelas IV SD Muhammadiyah Pringsewu Lampung dalam menyerapkan pengetahuan dan kemampuan kognitif setelah mendapatkan pembelajaran Tematik untuk Tema 1 dengan menggunakan pendekatan Saintifik.

Penelitian akan dilaksanakan melalui tiga siklus yang akan dipergunakan untuk melihat bagaimana Menumbuhkembangkan Civic Literacy melalui penggunaan Model Berbasis Pendekatan Pembelajaran Saintifik Dengan Menggunakan Media Belajar Aplikasi Komputer Pro Gold Show. Ketiga siklus ini mencakup kegiatan perencanaan (planning), tindakan (acting), pengamatan (observing), dan Refleksi (Reflecting).
Pada tahapan Perencanaan Penelitian Tindakan dipersiapkan dengan menyiapkan berbagai Instrumen yang akan dipergunakan untuk memberikan perlakuan dalam Pembelajaran yakni; Silabus/RPP/SAP yang merupakan Blue Print perencanaan pembelajaran yang akan dilaksanakan selama satu semester.Selanjutnya hasil temuan akan direfleksikan yang kemudian akan dievalusi apabila belum menemukan hasil yang memuaskan akan diulang kembali.

Pengumpulan data dalam penelitian ini menggunakan teknik pengamatan, tanya jawab atau konsultasi, hasil pre dan post test sebelum dan sesudah melakukan tindakan, catatan harian / Jurnal penelitii, wawancara, rekaman kamera dan recorder, dan catatan hasil observasi harian.

Keabsahan data penelitian ini diperiksa melalui triangulasi yakni teknik pemeriksaan keabsahan data dengan menggunakan pengamat lain untuk menilai tingkat kepercayaan data kita yang dilihat melalui 3 (tiga) sumber yakni; 1) catatan harian penelitian; 2) catatan dari kolaborator.

Analisis dilakukan untuk mengembangkan model hipotetik dengan menggunakan pendekatan kualitatif Pendekatan Kualitatif dilakukan dengan menggunakan Data yang terkumpul dari setiap kegiatan observasi, wawancara, dan pengisian kuisioner pada setiap siklus akan dianalisis secara kualitatif dalam bentuk deskripsi dengan menggunakan teknik menyusun kategori sandi dalam sebuah matriks, setelah itu akan dianalisis menggunakan analisis SWOT (Strenghts Weakness Opportunities Threats).

\section{PEMBAHASAN}

\section{a. Menumbuhkan Civic Literacy melalui Pembelajaran dengan menggunakan Pendekatan Saintifik.}

Menumbuhkan Civics Literacy yang berupa kemampuan yang terdiri dari Civics Knowledge (Pengetahuan), Civics Skill (Kecakapan) dan Civics Disposition (watak) merupakan keniscayaan yang harus dikembangkan 
di abad Ke-21 karena akan dihadapkan pada suatu kondisi perubahan cepat karena sekat sosial budaya dari tiap Negara akan roboh, Kondisi dikenal sebagai globalisasi (Arpannuddin, 2016:368)

Civic Literacy, berasal dari istilah "Literacy" yang diserap ke dalam bahasa Indonesia melalui berbagai Istilah penyebutan antara lain; "Kemelekwacanaan", átau "Melek Wacana", dan "Literasi" yang juga merupakan kata serapan dari Bahasa Latin "Littera" bermakna huruf, kemudian apabila dikaitkan dengan konteks kewarganegaraan seringkali diindentikkan sebagai "Political Literacy" atau "Civic Literacy" yang oleh Suryadi (Arpannudin, 2016:369) dijelaskan sebagai suatu pengetahuan dan kemampuan seorang warga negara untuk mengatasi permasalahan sosial, politik, dan kenegaraan.

Mengenai Civic Literacy berdasarkan pemikiran Benavot (Arpannudin, 2016:370) terdapat tujuh aspek Literasi yakni; 1) Literasi mengenai bagaimana membangun sinergisitas antara kebijakan pembangunan dan kebutuhan masyarakat; 2) Literasi mengenai Koordinasi antar institusi negara; 3) Literasi mengenai Lembaga-lembaga pemerintahan, Ormas, LSM dan Lembaga keagamaan; 4) Literasi bagaimana menjaga independensi, dan imparsialitas dalam kehidupan berbangsa dan bernegara; 5) Literasi yang memungkinkan Individu untuk memperoleh keterampilan mata pencaharian yang meningkatkan kerja dan produktivitas mereka; 6) Literasi mengenai hubungan antar generasi; dan 7) Literasi mengenai bagaimana menjaga hubungan antara ruang publik dan swasta.

Civic Literacy ini akan meliputi pengetahuan mengenai Negara, Pemerintahan dan Peran Warga negara, jadi dapat dikatakan secara sederhana Civic Literacy adalah Civic Knowledge, Civics Skill, dan Civics Disposition.
Pencapaian pembentukan Civic Literacy hendak dicapai melalui proses pembelajaran di persekolahan, dalam hal ini pembelajaran mata pelajaran Pendidikan Kewarganegaraan yang menurut Kementrian Pendidikan Nasional pada tahun 2004 (Winarno, 2011:117) materi keilmuan mata pelajaran Pendidikan Kewarganegaraan mencakup pengetahuan kewarganegaraan (civic knowledge), keterampilan kewarganegaraan (civic skills), dan nilai-nilai kewarganegaraan (civic values), sehingga dapat kita simpulkan bahwa mata pelajaran Pendidikan Kewarganegaraan yang memiliki misi pedagogis untuk membentuk Civic Literacy dalam dunia persekolahan. Materi pengetahuan kewarganegaraan (Civic Knowledge) meliputi keilmuan bidang politik, hukum, dan moral yang mencakup pengetahuan mengenai prinsip dan proses Demokrasi, Lembaga Pemerintahan dan Non Pemerintahan, Identitas Nasional, Pemerintahan Berdasarkan Hukum, Peradilan yang Bebas dan Tidak Memihak, Korupsi, Sejarah Nasional, Hak dan Kewajiban warga Negara, Hak Asasi Manusia, Hak Sipil dan Politik.

Seperti apa yang dikemukakan UNESCO (Nasution, 2013:12-12, Aprillia dan Nurjannah, 2017:88) terdapat enam kategori kebutuhan kemampuan Literasi bagi warga negara di abad 21 yakni; basic literacy, computer literacy, media literacy, distance literacy dan e-learning, cultural literacy, serta information literacy.

Dikaitkan dengan apa yang harus dipahami sebagai seorang warga negara, tentunya berupa pengetahuanpengetahuan mengenai; Negara, Pemerintahan dan Peran Warga negara. $\mathrm{Di}$ mana menurut Permendiknas No. 22 Tahun 2006 (Winarno, 2013:118) meliputi wawasan tentang: a) persatuan dan kesatuan bangsa; b) norma, hukum dan peraturan; c) hak asasi manusia; d) kebutuhan warga negara; e) konstitusi 
negara; f) kekuasaan dan politik; g) pancasila; dan h) globalisasi.

Kemampuan literasi dapat dikatakan sebagai jantung atau core kemampuan peserta didik dalam mendapatkan mengolah, dan mengkomunikasikan informasi selama proses belajar, dan sudah selayaknya ditanamkan sejak sekolah dasar.

Untuk itulah kemudian berdasarkan Permendikbud No 23 Tahun 2015 . (Ditjen Dikdasmen Kemendikbud RI, 2016:1-2) digulirkan Gerakan Literasi Sekolah (GLS) sebagai upaya yang dilakukan secara menyeluruh untuk menjadikan sekolah sebagai organisasi pembelajaran yang warganya literat sepanjang hayat melalui pelibatan publik

Adapun tujuannya secara umum adalah menumbuhkembangkan budi pekerti peserta didik melalui pembudayaan ekosistem literasi sekolah yang diwujudkan dalam Gerakan Literasi Sekolah agar mereka menjadi pembelajar sepanjang hayat, kemudian secara khusus yaitu; a) Menumbuhkembangkan budaya literasi sekolah; b) Meningkatkan kapasitas warga dan lingkungan sekolah agar literat; c) Menjadikan sekolah sebagai taman belajar yang menyenangkan dan ramah anak agar warga sekolah mampu mengelola pengetahuan; d) Mampu keberlanjutan pembelajaran dengan menghadirkan beragam buku bacaan dan mewadahi berbagai strategi membaca.

Menurut Beers (Andriani, 2017:121) praktik-praktik yang baik dalam Gerakan Literasi Sekolah harus menekankan prinsip-prinsip; a) Perkembangan Literasi akan berjalan baik apabila disesuaikan dengan tahap peerkembangan peserta didik; b) Program Literasi yang berimbang; c) Program Literasi harus terintegrasi dengan Kurikulum; d) kegiatan membaca dan menulis dilakukan kapanpun; e) kegiatan literasi mengembangkan budaya Lisan; f) Kegiatan literasi perlu mengembangkan kesadaran terhadap keberagaman.
Dalam kaitannya dengan Civic Literacy tentunya kepada Literasi yang berkaitan dengan Informasi pengetahuan mengenai isyu-isyu sosial kenegaraan dalam bentuk cetak, visual, dgital, dan auditori, sehingga dapat dikatakan sebagai salah satu bentuk kemampuan Literasi Informasi. Di mana menurut Ferguson (Ditjen Dikdasmen Kemendikbud RI, 2016:61) Literasi informasi itu terdiri dari;1) Literasi Dasar (Basic Literacy) berupa kemampuan mendengarkan, berbicara, membaca, menulis, dan menghitung; 2) Literasi Perpustakaan (Library Literacy) yakni kemampuan lanjutan untuk meningkatkan mencari, dan menyerap bahan pustaka sebagai jalan mendapat Informasi; 3) Literasi Media (Media Literacy) adalah suatu kemampuan untuk mengetahui dan mengakses informasi dari media cetak, media elektronik, media digital dan memahami tujuan penggunaannya.

Menurut Wina Sanjaya (2011:77) Pendekatan merupakan suatu titik tolak atau sudut pandang terhadap suatu proses tertentu, maka apabila kita akan melaksanakan suatu bentuk kegiatan terutama dalam pembelajaran penting sekali untuk menentukan pendekatan seperti apa yang akan dilakukan.

Kurikulum 2013 secara filosofis menyarankan anak harus dikembangkan berdasarkan perkembangnya, dengan memperhatikan berbagai sisi tidak hanya yang bersifat material akan tetapi immaterial harus pula diperhatikan, oleh karena itu pendekatan yang sebaiknya dipergunakan adalah pendekatanpendekatan yang bersifat mendorong kerja sama, toleransi, kerja keras, integritas, disiplin, bermoral dan tanggung jawab.

Pendekatan Saintifik merupakan salah satu rekomendasi Kurikulum 2013 dalam melaksanakan pembelajaran, di karenakan dapat mengarahkan siswa untuk meneliti dan berpikir secara sistematis yang 
kemudian untuk mengambil kesimpulan sebagai proses berpikir ilmiah yang selazimnya.

Pendekatan pembelajaran Saintifik ialah satu pendekatan dalam pembelajaran dengan cara memberikan stimulan pada siswa agar ia aktif untuk mengkonstruksikan konsep, prinsip atau teori melalui tahapan-tahapan mengamati, menanya, menalar mengumpulkan informasi, menganalisis data dan menarik kesimpulan yang kemudian siswa akan komunikasi berdasarkan temuannya (Ditjen Dikdasmen Kemendikbud RI, 2016:21). Karakter dan tujuan mendasarkan pada Prinsip-Prinsip; 1) Student Centered Learning Oriented (SCL) artinya segala aktivitas belajar berpusat pada siswa; 2) bukan hanya sekedar transfer pengetahuan akan tetapi berupa pengembangan pengetahuan siswa; 3) pengembangan kemampuan berpikir siswa; 4) Merupakan Pelatihan kemampuan keterampilan berproses IImiah; 5) Selalu melakukan Validasi dalam konsep, prinsip atau teori.

\section{b. Penggunaan Media dalam Pendekatan Saintifik.}

Berdasarkan uraian sebelumnya kita mengetahui bahwa kerangka utama dalam kegiatan pembelajaran berbasis pendekatan saintifik adalah berupaya meningkatkan kemampuan berpikir siswa dengan mengisi pengetahuan-pengetahuan pada kapasitas berpikirnya.

Pengisian pengetahuan oleh Guru terhadap Siswa merupakan transfer pengetahuan yang dijalankan dengan melakukan komunikasi dua arah antara Guru dan muridnya. Dalam pelaksanaannya tentunya membutuhkan media sebagai alat yang dipergunakan untuk menyampaikan pesan dan kesan pengetahuan.

Media belajar adalah segala sesuatu yang dipergunakan untuk menyalurkan pesan dalam berkomunikasi ketika kegiatan belajar mengajar berlangsung (Mumpuni, 2017:97). Penggunaan Media dalam belajar sangat diperlukan karena tiaptiap murid memiliki gaya belajar yang berbeda-beda, sehingga memerlukan pemilihan media yang tepat sesuai dengan gaya belajar yang dimiliki siswa dan arahan dari pendekatan yang dipergunakan.

Secara umum gaya belajar siswa terbagi dalam tiga macam bentuk gaya belajar yaitu: 1) gaya belajar visual yang menekankan pada penglihatan; 2) gaya belajar auditori yang lebih menekankan pada pendengaran; dan 3) gaya belajar kinestetik yang lebih menekankan pada gerakan untuk melakukan sesuatu dalam menelaah informasi belajar.

Untuk itu Media Motion Visual seringkali disebut pula sebagai media audio visual yang memiliki karakteristik menyatukan antara suara dan gambar secara menyatu, dalam hal media audio visual disajikan melalui penggunaan perangkat yang berkaitan dengan istilah hardware (Perangkat Keras) dan Software (Perangkat Lunak).

Untuk Perangkat Keras dikenal penggunaan Komputer atau Multimedia sebagai Equipment dalam memindahkan atau menyampaikan sesuatu yakni materi pembelajaran, Sementara itu Perangkat Lunak merupakan isi pesan atau sistem yang dipergunakan dalam penyampaian materi.

Diantara berbagai macam perangkat lunak yang dipergunakan dalam perangkat pembelajaran dikenal Program atau aplikasi yang bernama Pro Show Gold. Perangkat Lunak ini mampu menyatukan berbagai frame photo dalam sekali penampilan, sehingga dapat dipergunakan untuk merancang media media pembelajaran Media Audio Visual.

Mengenai Penggunaan Media Audio Visual ini Slamet (2015:69) berkesimpulan dalam penelitian tindakan yang berjudul "Peningkatan Kemampuan Menjelaskan Keanekaragaman Suku dan Budaya Indonesia Melalui Media Audio Visual" 
bahwa Penggunaan Audio Visual dalam pembelajaran Pendidikan Kewarganegaraan dapat meningkatkan partisipasi dan prestasi belajar siswa. Selain itu dapat pula meningkatkan kinerja mengajar guru.

Begitu pula dengan temuan penelitian yang dilaksanakan oleh Novia dkk (2014:61) yang berkesimpulan Penggunaan Media Audio Visual dapat meningkatkan kualitas pembelajaran yang meliputi; keterampilan guru, aktivitas siswa dan hasil belajar.

\section{c. Hasil Penelitian Tindakan}

\section{Gambaran Umum}

Pembelajaran Tematik yang dilaksanakan di Kelas IV SD Muhammadiyah Pringsewu Lampung dilaksanakan secara Seperated Curricular di mana tiap-tiap bidang studi yang berada dalam lingkup pembelajaran Tematik diajarkan secara terpisah meliputi; Mata Pelajaran Pendidikan Pancasila dan Kewarganegaraan (PPKn), IImu Pengetahuan Sosial (IPS), IImu
Pengetahuan Alam (IPA), Bahasa Indonesia dan Seni Budaya dan Keterampilan.

\section{Perencanaan}

Langkah-langkah pada tahapan perencanaan meliputi: 1) Pemilihan Masalah yang terdiri dari a) Studi awal, b) Penentuan Masalah; 2) Studi Pendahuluan; 3) Pengajuan Izin Penelitian; 4) Rekayasa Multimedia produk yang akan diuji.

\section{Siklus I}

Hasil Pelaksanaan Langkah-langkah tindakan dalam Siklus I ini meliputi;

1) Penyusunan Perencanaan pembelajaran melalui: a) Konsultasi antara Peneliti dan Guru, b) Penyusunan RPP antara Guru dan Peneliti;

2) Pelaksanaan Pre Test dan Post Test Pencapaian Nilai N-Gain antara Nilai Pre Test dan Post Test Siklus I ini di dapat a) nilai tertinggi 0.38 Nilai, b) Nilai Terendah -1.25, dan c) rata-rata 0.0031 . yang dapat digambarkan.

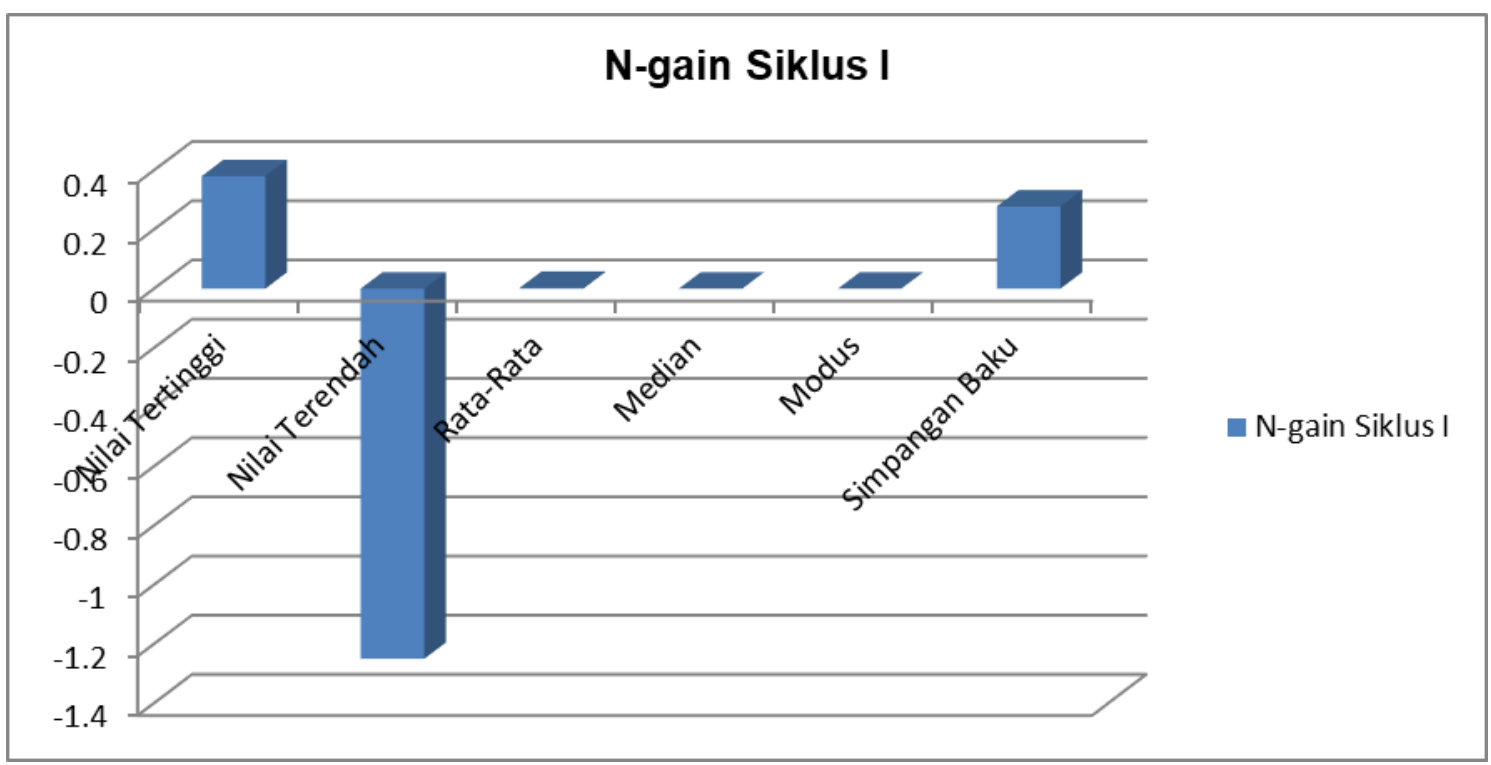

Gambar 1. Hasil Pre Test dan Post Test Siklus I

3) Pelaksanaan Tindakan didapat hasil yang dapat teramati dalam observasi yakni; a) upaya apersepsi 13 kali, b) upaya penguasaan materi 12 kali, c) upaya menerapakan strategi pembelajaran 27 kali; d) memanfaatkan media 10, dan e) melibatkan peserta didik terlihat 4 kali, sehingga untuk observasi dapat terlihat: a) 
ketertarikan siswa untuk memperhatikan materi; b) rasa ingin tahu mengenai materi Civics Literacy sudah mulai tumbuh; c) Guru masih kesulitan dalam merapkan materi;

Dengan demikian dari gambaran indikator pengukuran dan hasil observasi maka Refleksi dan Evaluasi bahwa Pembelajaran Tematik menggunakan Media Belajar Audio Visual berbasis Pro Show Gold untuk meningkatkan Civics Literacy terdapat Kesimpulan a) Tindakan Menggunakan Media Belajar berbasis Program Pro Show Gold dalam pembelajaran Tematik dengan Pendekatan Saintifik yang telah dilaksanakan telah memberikan kontribusi yang cukup baik terhadap Upaya menumbuhkan Civics Literacy: b) Walaupun telah memberikan Kontribusi akan tetapi perlu ada perbaikan agar pelaksanaan
Tindakan Menggunakan Media Belajar berbasis Program Pro Show Gold dalam pembelajaran Tematik dengan Pendekatan Saintifik; dan c) Direkomendasikan agar tayangan disusun dengan lebih memperhatikan kemampuan Siswa dalam memahami.

\section{Siklus II.}

Refleksi dan Evaluasi dilaksanakan untuk siklus II, kemudian Guru dan peneliti berkonsultasi untuk mempelajari silabus dan menyusun RPP yang menjadi pedoman dalam tindakan di Siklus II.

Seperti halnya dalam siklus II dilaksanakan kembali Pre Test dan Post Test dengan hasil N-Gain adalah a) nilai tertinggi 0.80 Nilai, b) Nilai Terendah -2.00 , dan c) rata-rata 0.19 , apabila kita perbandingkan dengan nilai $\mathrm{N}$-Gain pada siklus II maka dapat tergambar pada gambar 2 .

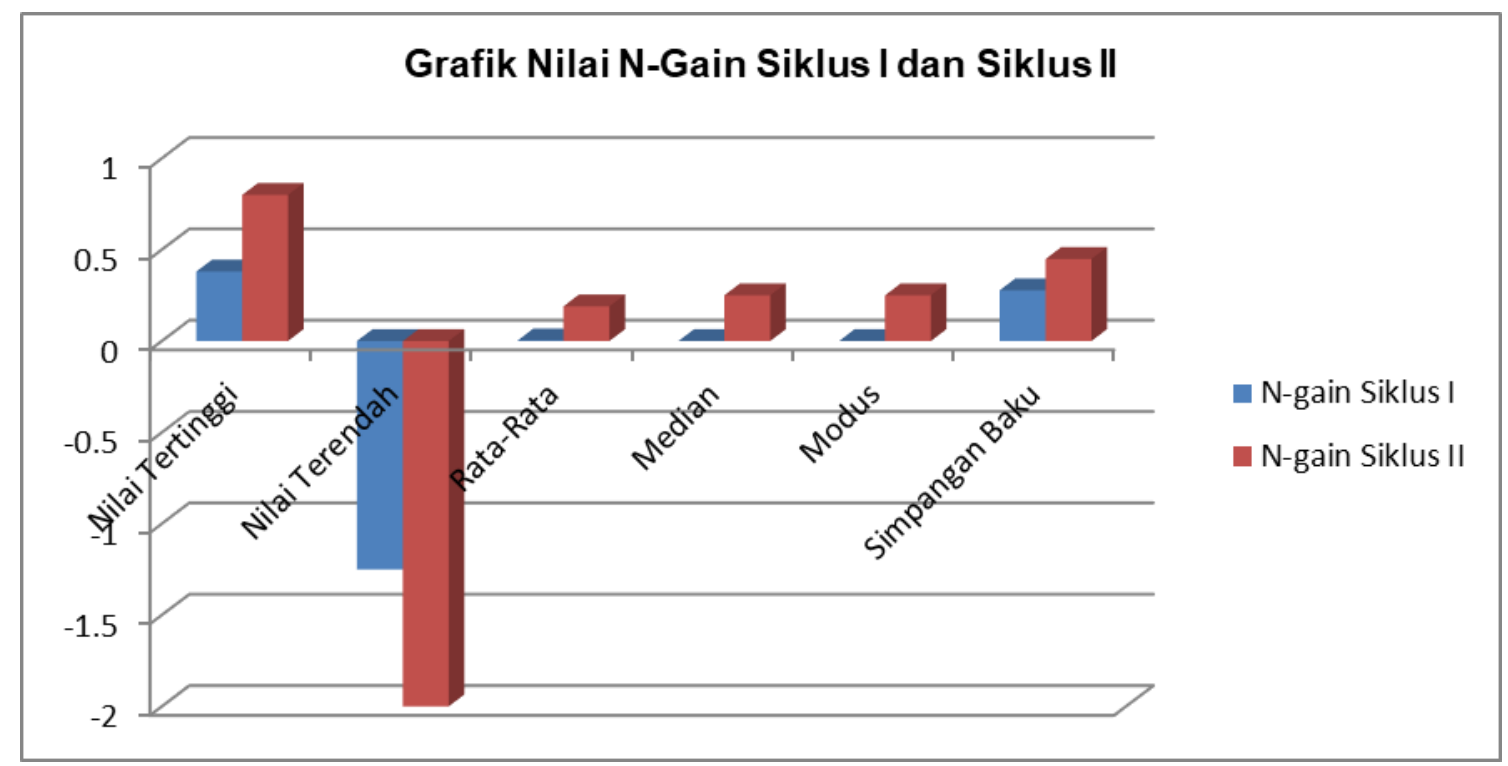

Gambar 2. Gambar 1. Hasil Pre Test dan Post Test Siklus II

Ketika melaksanakan Tindakan dilaksanakan Observasi dengan hasil pengamatan sebagai berikut: a) upaya apersepsi 9 kali, b) upaya penguasaan materi 6 kali, c) upaya menerapakan strategi pembelajaran 20 kali; d) memanfaatkan media 10, dan e) melibatkan peserta didik terlihat 21 kali, dengan hasil a) terdapat penumbuhan ketertarikan terhadap materi civics literasi untuk dipelajari; b) siswa mulai terlihat secara psikologis memiliki respons belajar; c) Guru mulai terbiasa menggunakan media multimedia.

Dari uraian yang telah disampaikan diatas maka dapat disimpulkan bahwa a) tindakan pada siklus II ini telah mengalami perbaikan dalam hal 
pemberian Tindakan, akan tetapi terdapat beberapa kesalahan sehingga pencapaian N-Gain atau hasil belajar kurang memuaskan; dan b) Perlu ada perbaikan dalam hal penggunaan Metode Ajar atau penyampaian materi karena sepertinya pesan-pesan pengetahuan yang disampaikan kurang ditangkap oleh siswa, walaupun peningkatan motivasi belajar sudah cukup baik

\section{Siklus III}

Temuan yang didapat dari siklus II kemudian direfleksi lalu dievaluasi oleh Guru dan Peneliti, di mana hasilnya dipakai menjadi rujukan dalam menyusun RPP sebagai blue print pelaksanaan tindakan di siklus III.

Pre Test dan Post yang dilaksanakan pada siklus III menunjukkan hasil $\mathrm{N}$-Gain a) nilai tertinggi 0.80 Nilai, b) Nilai Terendah 2.00 , dan c) rata-rata 0.24 , apabila kita perbandingkan maka akan didapat gambaR 3.

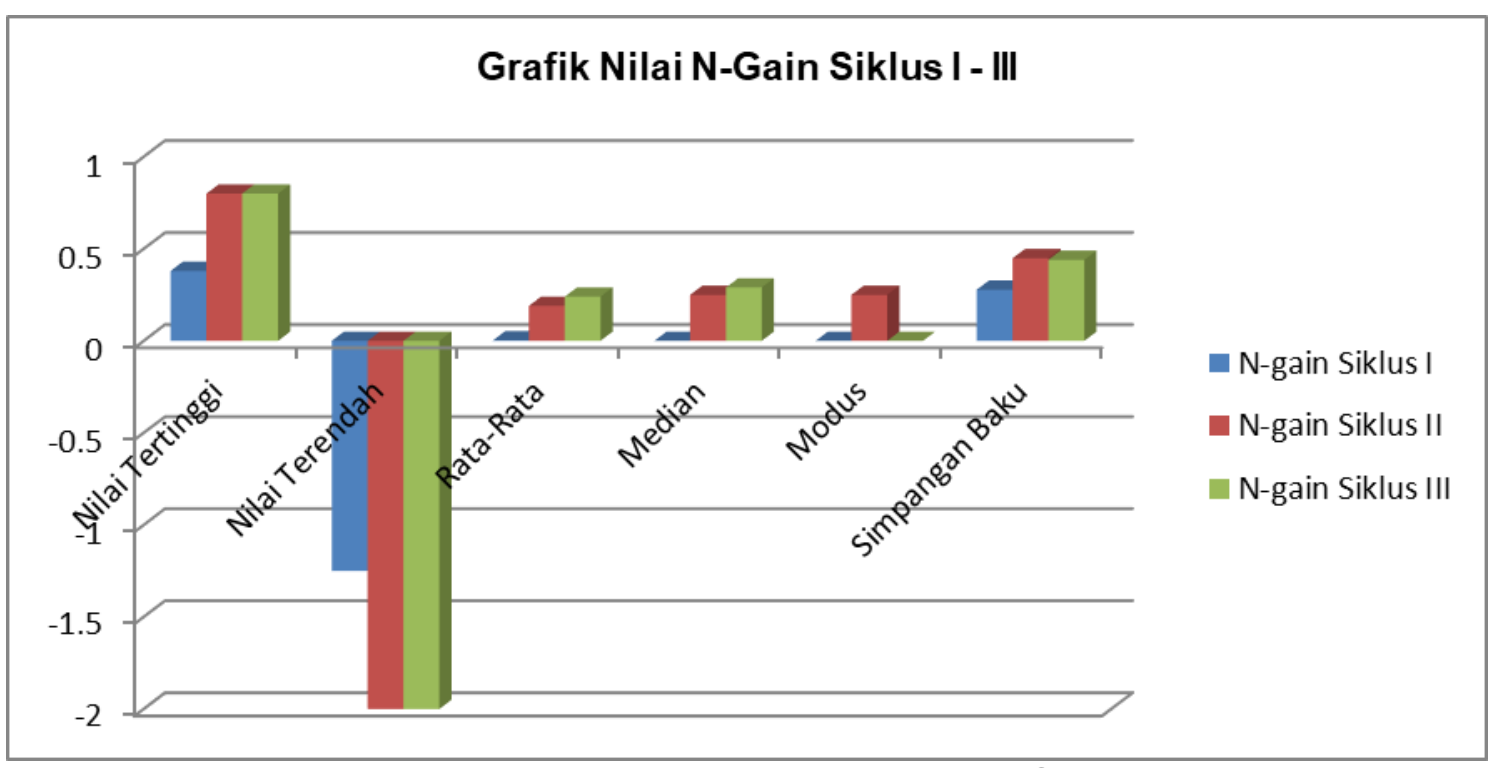

Gambar 3. Hasil Pre Test dan Post Test Siklus III

Kemudian apabila kita lihat apakah ada kenaikan dan penurunan pencapaian
N-Gain dari Siklus I-III maka dapat kita lihat melalui Gambar 4. 


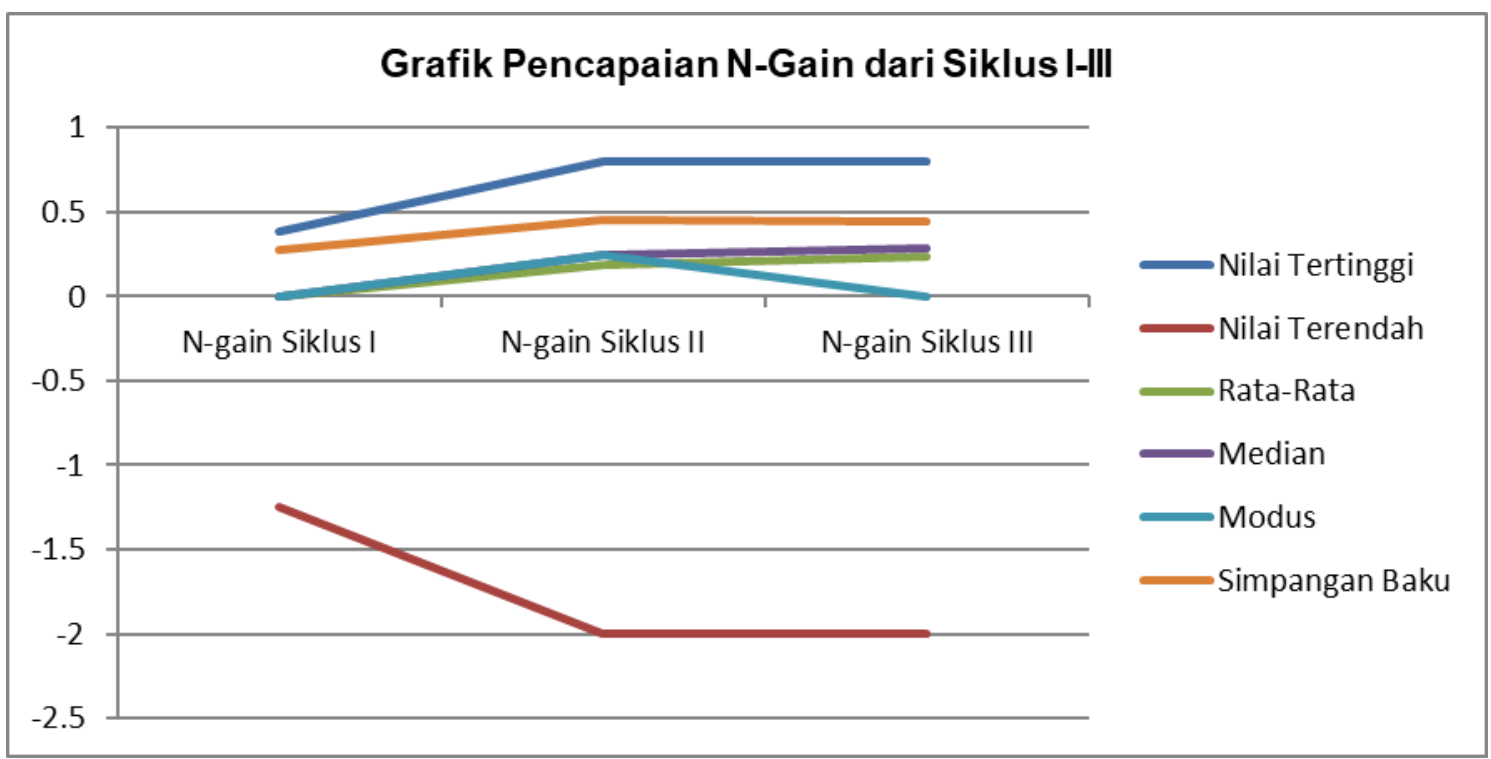

Gambar 4. Grafik Pencapaian N-Gain dari Siklus I-III

Sedangkan hasil observasi menunjukkan temuan a) upaya apersepsi 9 kali, b) upaya penguasaan materi 6 kali, c) upaya menerapakan strategi pembelajaran 20 kali; d) memanfaatkan media 10, dan e) melibatkan peserta didik terlihat 21 kali dari pelaksanaan Observasi itu maka didapat a) Siswa sudah mulai terbiasa malah menuju kecenderung bosan terhadap tindakan: b) Literasi sudah tampak, akan tetapi kebosanan mempelajari materi mulai terlihat; c) Guru terlihat sangat menikmati pembelajaran dengan menggunakan Media berbasis multimedia.

Sehingga didapatlah kesimpulan pada siklus III adalah; a) Telah terbukti penggunaan Penggunaan Media Audio Visual berbasis Program Aplikasi Komputer Pro Show Gold dalam pembelajaran Tematik dengan Pendekatan Saintifik dapat mampu membantu Guru untuk meningkatkan Motivasi dan Hasil Belajar siswa. b) Walaupun Penggunaan Media Penggunaan Media Audio Visual berbasis Program Aplikasi Komputer Pro Show Gold dalam pembelajaran Tematik dengan Pendekatan Saintifik dapat mampu membantu Guru untuk meningkatkan Motivasi dan Hasil Belajar siswa, akan tetapi keberhasilan pelaksanaannya bergantung pada kemampuan guru untuk melaksanakannya. d) Direkomendasikan Guru untuk menggunakan Media yang dapat memacu daya tangkap siswa dalam mengkaji materi terutama dalam pembelajaran Tematik karena pembelajaran bersifat Cross Curricular.

\section{Analisis SWOT}

Dalam pelaksanaan

Pembelajaran Tematik yang dilaksanakan dalam Tindakan hasil analisis adalah; Kekuatan: Pembelajaran Tematik dapat menyederhanakan pembelajaran, sehingga peserta didik tidak perlu lagi diberi beban belajar yang besar untuk meng-kaji suatu masalah. Kelemahan: Pembelajaran Tematik bersifat Integrated Curricular akan tetapi dalam pelaksanaannya masih bersifat Cross Curriular. Peluang: Pengembangan Pembelajaran Tematik masih terbuka secara inovatif. Ancaman: Secara Praktis Pembelajaran Tematik tidak akan tercapai tujuan pembelajarannya apabila Tenaga Pendidik kurang mampu menjalankan secara Pedagogik maupun Administratif.

Penggunaan Pendekatan Pembelajaran Saintifik hasil analisisnya adalah Kekuatan: Penggunaan 
Pendekatan Saintifik telah mampu meningkatkan tingkat partisipatif siswa dalam belajar melalui kegiatan mengamati, Menanya, Mengumpulkan Informasi, Mengasosiasikan, Mengkomunikasikan Kelemahan Porsi Keterlibatan Peserta Didik terlalu besar dalam Pembelajaran sehingga memerlukan perhatian yang khusus dalam inovasi pembelajaran Peluang: Penggunaan Pendekatan Saintifik sangat tepat di-terapkan dalam Pembelajaran Tematik dikarenakan lebih mengutamakan Pendekatan Inquiry yang lebih mengandalkan keaktifan siswa. Ancaman: Pendekatan Saintifik lebih mengedepankan keaktifan siswa, apabila Guru dapat menjaga ritme motivasi belajar siswa pada kondisi tinggi, maka kemungkinan tujuan pembelajaran akan sulit dicapai.

$$
\text { Penggunaan }
$$

Media

Pembelajaran Berbasis Multi Media dengan Program Pro Show Gold adapun hasil analisisnya adalah Kekuatan: Media Multimedia berbasis Pro Show Gold telah dapat menyuguhkan Media yang bersifat Audio Visual, sehingga telah mampu menyajikan materi pembelajaran yang interaktif dan mampu meningkatkan rasa antusiasme dan motivasi belajar siswa. Kelemahan: Tidak semua Guru atau Tenaga Pendidik memiliki kemampuan mengoperasikan Media Pembelajaran berbasis teknologi Multimedia dan Komputer. Peluang:
Pengembangan Inovasi Teknologi Media Pembelajaran berbasis teknologi Multimedia dan Komputer, masih sangat terbuka untuk dikembangkan. Ancaman: Penggunaan Teknologi Multimedia berbasis Pro Show Gold sebagai Media pembelajaran sedikit demi sedikit akan menggantikan Media Konvensional yang bersifat visual belaka yang lebih membentuk Guru untuk lebih kreatif.

Kemampuan Civics Literacy Siswa Sekolah Dasar di gambarkan dalam analiss Kekuatan: Kemampuan Civics Literacy harus dimiliki secara baik oleh siswa karena merupakan bekal kelak ketika ia akan menjadi sosok Warga Negara yang Good and Smart Citizenship Kelemahan: Penumbuhan Civics Literacy di kalangan siswa Sekolah dasar masih dianggap sebagai pembekalan pengetahuan belaka mengenai kehidupan bermasyarakat, padahal tidak hanya pembekalan pengetahuan akan tetapi juga meliputi pembentukan karakter. Peluang: Menumbuhkan Civics Literacy pada Siswa dapat senantiasa terus dikembangkan baik secara Integrated Curricular,dan Cross Curricular, akan tetapi dapat pula secara separated curricural. Ancaman: Kemampuan Civics, Literacy pada siswa apabila tidak diberi bekal sejak dini akan menjadi ancaman pada pengembangan karakter siswa selanjutnya.

\section{SIMPULAN}

Secara umum di dapat kesimpulan 1) Tingkat kemampuan Civics Literacy Siswa Kelas Tinggi SD Muhammadiyah dapat terlihat dari hasil pengukuran kemampuan menjawab dalam Pre test dan Post pada tiap siklus menunjukkan tingkat kemampuannya masih rendah.2) Langkah-langkah Penggunaan Model berbasis pembelajaran saintifik dengan menggunakan media belajar aplikasi komputer Pro Gold Show untuk menumbuhkembangkan civic literacy siswa sekolah dasar pada siswa kelas tinggi SD Muhammadiyah Pringsewu Lampung meliputi Studi kebutuhan, Tahapan Perencanaan, Tahapan Rekayasa Multi Media Produk, Tahapan Tindakan dan Tahapan Evaluasi. Secara garis besar penggunaan Model berbasis pembelajaran saintifik dengan menggunakan media belajar aplikasi komputer Pro Gold Show untuk menumbuhkembangkan civic literacy siswa Sekolah Dasar pada siswa kelas 
tinggi SD Muhammadiyah Pringsewu Lampung memberikan dampak pada Rasa Antusiasme siswa, Motivasi siswa dan Hasil belajar siswa sehingga dapat dikatakan dapat membantu Guru dalam mengembangkan Inovasi pembelajaran.4) Menumbuhkembangkan Civics Literacy Melalui Model Berbasis Pendekatan Pembelajaran Saintifik dengan Menggunakan Media Belajar Aplikasi Komputer Pro Show Gold memiliki kekuatan: Dapat memberikan pelayanan transformasi pengetahuan yang lebih efektif dan sederhana, melalui serangkaian tahapan Tindakan, Kelemahan: Pembelajaran dengan menggunakan gaya lama yang bersifat Cross Curricular akan menghambat inovasi dan improvisasi: Peluang: Masih terbuka Inovasi dan Improvisasai dalam pengembangannya;

Ancaman:

Kreativitas yang tidak terbentuk akibat kekurangan kemampuan Guru akan mengakibatkan Tindakan dalam pembelajaran menjadi sia-sia

Rekomendasi yang diberikan kepada Pendidik dan Tenaga Pendidik serta seluruh Stake Houlder di bidang Pendidikan untuk:

1. Untuk selalu dan senantiasa mengembangkan kemampuan Civics Literacy kepada siswa sejak dini, karena hal ini sangat mendesak untuk dilaksanakan di tengah kondisi sosial politik dewasa ini tidak hanya melalui pengembangan pengetahuan, akan tetapi harus pula meliputi pengembang Karakter, sehingga dapat membentuk Warga Negara yang Good and Smart Citizenship.

2. Pengembangan Inovasi pembelajaran berbasis teknologi merupakan suatu keniscayaan yang harus kita upayakan dan harus senantiasa dikembangkan melalui berbagai langkah dan tindakan yang tepat guna.

\section{DAFTAR PUSTAKA}

Andriani, Ana. (2017). Kajian The Body Of Knowledge Pendidikan Kewarganegaraan Dalam konteks Pembelajaran Di Sekolah Dasar Guna Meningkatkan Literasi Hukum. Prosiding Seminar Nasional PGSD Prodi PGSD FKIP Universitas Muhammadiyah Purwokerto. Purwokerto 10 Mei 2017.

Aprillia, Seni. dan Anis Nurjanah. (2017). Pembelajaran Berbasis Permainan Tradisional sebagai afirmasi Literasi Budaya Di Sekolah Dasar. Prosiding Seminar Nasional PGSD Prodi PGSD FKIP Universitas Muhammadiyah Purwokerto. Purwokerto 10 Mei 2017.

Arpannudin, lqbal. (2016). Literasi Warga Negara Muda untuk Mengembangkan Civic Engagement Di Abad 21. Prosiding Seminar Internasional
Pendidikan Kewarganegaraan Laboratorium Pendidikan Kewarganegaraan Universitas Pendidikan Indonesia. Bandung, Selasa 15-16 November 2016.

Emzir. (2011). Metodelogi penelitian Pendidikan Kuantitatif dan Kualitatif. Jakarta: RajaGrafindo Persada.

Fatahillah. (2017). Identifikasi Kemampuan guru Dalam Penggunaan Strategi dan Metode Belajar Berdasarkan Arahan Kurikulum 2013 Sebagai Upaya Meningkatkan Literasi Siswa Sekolah Dasar. Prosiding Seminar Nasional PGSD Prodi PGSD FKIP Universitas Muhammadiyah Purwokerto. Purwokerto 10 Mei 2017.

Gipayana, Muhana. (2004). Pengajaran Literasi dan Penilaian Portofolio dalam Konteks Pembelajaran Menulis di SD. Jurnal IImu Pendidikan Universitas Negeri 
Malang Jilid II. Nomor 1. Februari 2004.

Mumpuni, Atikah. (2017). Peran Buku Pelajaran Dalam

Mengembangkan Karakter siswa Sekolah Dasar. . Prosiding Seminar Nasional PGSD Prodi PGSD FKIP Universitas Muhammadiyah Purwokerto. Purwokerto 10 Mei 2017.

Novia, Sari dkk. (2014). Peningkatan Kualitas Pembelajaran PKn Melalui Model Course Review Horey Media Audio Visual. Joyful Learning Journal Vol 3 No 2 Juni 2014. HIm 57-62.

Slamet. (2015). Peningkatan Kemampuan Menjelaskan Keanekaragaman Suku dan Budaya melalui Media Audio Visual. Jurnal Dinamika Vol 5. No 4. Oktober 2015. HIm 61-69.

Sanjaya, Wina. (2011). Kurikulum dan Pembelajaran. Cet 11. Jakarta: Kencana.

Tim Penyusun Ditjen Dikdasmen Kemendikbud RI. (2016). Panduan Gerakan Literasi Sekolah Di Sekolah Dasar. Jakarta: Direktorat Jenderal Pendidikan Dasar dan Menengah Kementrian Pendidikan dan Kebudayaan RI.

Tim Penyusun Ditjen Dikdasmen Kemendikbud RI. (2016).
Panduan Teknis Pembelajaran dan Penilaian di Sekolah Dasar. Jakarta: Direktorat Jenderal Pendidikan Dasar dan Menengah Kementrian Pendidikan dan Kebudayaan RI.

Tim Penyusun Ditjen Dikdasmen Kemendikbud RI. (2016). Panduan Gerakan Literasi Sekolah di Sekolah Dasar. Jakarta: Direktorat Jenderal Pendidikan Dasar dan Menengah Kementrian Pendidikan dan Kebudayaan RI.

Ubaidillah, A. dkk. (2000). Pendidikan Kewargaan Demokrasi, HAM, dan Masyarakat Madani. Jakarta: IAIN Syarif Hidayatullah Press

Wahab, Abdul Aziz. Dan Sapriya. (2011). Teori dan Landasan Pendidikan Kewarganegaraan. Bandung: Alfabeta.

Winarno. (2013). Pembelajaran Pendidikan Kewarganegaraan Isi Strategi dan Penilaian. Jakarta: Bumi Aksara.

Winataputra, dan Budimansyah. (2007). Civic Education: Konteks Landasan, Bahan Ajar dan Kultur Kelas. Bandung: Program Studi Pendidikan Kewarganegaraan Sekolah Pascasarjana Universitas Pendidikan Indonesia 